\title{
NOVELTIES IN THE ORCHID FLORA OF VENEZUELA II - CRANICHIDEAE*
}

\author{
Gustavo A. Romero-GonzÁlez ${ }^{1}$, Germán Carnevali Fernández-Concha² \\ \& PAUL ORMEROD ${ }^{3}$
}

\author{
${ }^{1}$ Oakes Ames Orchid Herbarium, Harvard University Herbaria, 22 Divinity Avenue, Cambridge, Massachusetts \\ 02138, U.S.A.romero@oeb.harvard.edu \\ ${ }^{2}$ Herbarium CICY, Centro de Investigación Científica de Yucatán A. C. (CICY), Calle 43, No. 130, Col. Chuburná \\ de Hidalgo, 97200 Mérida, Yucatán, México. carneval@cicy.mx \\ ${ }^{3}$ P.O. Box 8210, Cairns 4870, Queensland, Australia. wsandave@bigpond.net.au
}

\begin{abstract}
Aвstract. Two new orchid species in tribe Cranichideae, collected in the context of the project "Flora de Orquídeas de los Estados Amazonas y Bolívar, Venezuela" (Orchid Flora of Amazonas and Bolívar states, Venezuela") are described and illustrated. Ligeophila gavilanesis (subtribe Goodyerinae) is similar to $L$. unicornis but differs in having broader $(1.75-2.90$ versus $0.93-1.50 \mathrm{~cm})$ narrowly elliptic to oblonglanceolate (not lanceolate) leaves, flowers with oblong-lanceolate, obtuse (not broadly lanceolate, acute) epichile lobules, and an unappendaged (i.e., lacking an oblong, compressed projection) epichile. Sarcoglottis maroaënsis (subtribe Spiranthinae) is similar to $S$. metallica but the new species differs in the cream flowers with dark reddish veins in the sepals, petals, and labellum, and the leaves of different color. In flower color it is similar to S. ventricosa but the inflorescence of Sarcoglottis maroaënsis is more lax and not lanate, the flowers are smaller, and the lateral sepals and labellum are different. We report an isotype of Sarcoglottis stergiosii not cited in the protologue and a specimen collected in the Colombian Amazon.
\end{abstract}

Resumen. Se describen e ilustran dos nuevas orquídeas en la tribu Cranichideae colectadas en el contexto del proyecto "Flora de orquídeas de los estados Amazonas y Bolívar, Venezuela". Ligeophila gavilanensis (subtribu Goodyerinae) es similar a L. unicornis pero difiere por sus hojas más anchas $(1.75-2.90$ versus 0.93-1.50 cm), angostamente elípticas hasta oblongo lanceoladas (no lanceoladas) y flores con los lóbulos del epiquilo oblongo-lanceolados, obtusos (no anchamente lanceolados, agudos) y un epiquilo sin apéndice (careciendo de una proyección oblonga, comprimida). Sarcoglottis maroaënsis (subtribu Spiranthinae) es similar a $S$. metallica pero la nueva especie difiere por las flores color crema con venas rojizo oscuro en los sépalos, pétalos y labeloy por las hojas de color diferente. En color floral es similar a $S$. ventricosa pero las inflorescencias de Sarcoglottis maroaënsis son más laxas y no lanadas, las flores son menores y los sépalos laterales y el labelo son diferentes. Reportamos un isotipo de Sarcoglottis stergiosii no citado en el protólogo, así como un espécimen colectado en la Amazonía colombiana. También se incluye una clave para identificar las especies de Sarcoglottis reportadas para la Guayana venezolana.

Key word / Palabras clave: Amazonas, Bolívar, Guayana, Ligeophila, Sarcoglottis, Venezuela

The following two new species of Orchidaceae (Cranichideae) were collected in the context of the project " Flora de orquídeas de los estados Amazonas y Bolívar, Venezuela" (Orchid flora of Amazonas and Bolívar state, Venezuela").

* The first article in this series was published in Harvard Pap. Bot. 14 (2): 203-211. December 2009.
Subtribe Goodyerinae K1. (Garay, 1977, pro parte; Ormerod \& Cribb, 2003: 64).

Ligeophila Garay (Garay, 1977; Ormerod \& Cribb, 2003: 114; Ormerod, 2009).

Ligeophila gavilanensis Ormerod \& G. A. Romero, sp. nov.

TYPE: Venezuela. Amazonas: Municipio Autónomo 
Atures, río Gavilán, margen derecha (oeste) del río en las cercanías del raudal Gavilán," 120 m, 8 November 1996, "hierba terrestre, hojas verde-marrón con vetas longitudinales verdes, flores blancas, localmente frecuente pero pocos individuos en flor," G. A. Romero. L. M. Campbell \& C. Gómez 3066 (holotype: VEN; isotypes: TFAV, fragment AMES). FIg. 1A-B, 2.

Affinis Ligeophilae unicorni Ormerod, sed folia latiora ex anguste elliptico oblongo-lanceolata (non lanceolata), flores epichili lobulis oblongo-lanceolatis, obtusis (non late lanceolatis, acutis).

Terrestrial, erects herbs. Rhizome terete, rooting at nodes, lower half creeping, upper half erect, ca. 10.5 $\mathrm{cm}$ long; internodes $0.5-1.6 \times 0.15-0.30 \mathrm{~cm}$. Stem erect, laxly 4-5-leaved, $c a$. $10 \mathrm{~cm}$ long; internodes $1.35-3.20 \times 0.2-0.3 \mathrm{~cm}$. Leaves obliquely narrowly elliptic to oblong-lanceolate, subacuminate, margins undulate, green-maroon, $5.3-9.2 \times 1.75-2.90 \mathrm{~cm}$; petiole and sheath $0.9-2.6 \mathrm{~cm}$ long. Inflorescence terminal, pubescent, ca. $6.1 \mathrm{~cm}$ long; peduncle $c a$. $3.1 \mathrm{~cm}$ long; sheathing bracts 3 , overlapping, 1.5 $-1.8 \mathrm{~cm}$ long; rachis subdensely-flowered, ca. $3 \mathrm{~cm}$ long; floral bracts ovate-lanceolate, acute, to 13 x $5 \mathrm{~mm}$. Pedicellate ovary cylindric, pubescent, ca. $10 \mathrm{~mm}$ long. Flowers resupinate, externally pubescent. Dorsal sepal reddish-brown, ovatelanceolate, truncate, shallowly concave, $7.6 \times 3.2$ $\mathrm{mm}$. Lateral sepals green toward the base, reddish apically, obliquely oblong-lanceolate, obtuse, $8 \mathrm{x}$ $2.5 \mathrm{~mm}$. Petals white, with a medial reddish-black oblanceolate stripe, obliquely obovate-oblanceolate, acute, forming a hood with the dorsal sepals, 6.75 x $2.8 \mathrm{~mm}$. Labellum white, spurred, trilobed, joined to the ovary and to the column for $c a .2 .0 \mathrm{~mm}$; spur clavate, apex shortly obtusely bilobed, $6.5 \mathrm{~mm}$ long; hypochile in total $c a .3 .8 \mathrm{~mm}$ long, $c a .4 .2 \mathrm{~mm}$ wide, each side with a semiorbicular lobe $2.1 \mathrm{~mm}$ wide, terminating in an obliquely triangular extension directed forward and outward, outside each side with a fleshy patch upon a convexity (mirrored by an internal concavity); mesochile obcuneate, ca. 1.75 $\mathrm{mm}$ long, basally $c a .1 \mathrm{~mm}$ wide, apex $c a .1 .5 \mathrm{~mm}$ wide; epichile hippocrepiform, reflexed, with lobules pointing forward, medially $2.8 \mathrm{~mm}$ long, $6 \mathrm{~mm}$ wide, lobules oblong-lanceolate, obtuse, falcate, $c a .7 .75$ $\mathrm{mm}$ long from epichile tip to apex. Column with an elongate basally flexible rostellum, in total $5 \mathrm{~mm}$ long (description based on a dry specimen and flowers preserved in alcohol).

Etymology: Named after the type locality, Caño Gavilán, a small clear-water river that joins the Cataniapo river just west of the Huottuja (Piaroa) community of Gavilán.

Distribution: So far known only from the type locality.

Ligeophila gavilanensis appears to be most closely related to L. unicornis Ormerod, also from Venezuela, both species having a labellum hypochile with similar sidelobes. From the latter, however, the new species differs in having broader (1.75-2.90 versus 0.93 $1.50 \mathrm{~cm}$ ) narrowly elliptic to oblong-lanceolate (not lanceolate) leaves, and flowers with oblong-lanceolate, obtuse (not broadly lanceolate, acute) epichile lobules, and an unappendaged (i.e., lacking an oblong, compressed projection) epichile. Another species with a similarly shaped labellum hypochile is L. jamesonii Garay, from Colombia and Ecuador. The latter has a much larger inflorescence (rachis $>11 \mathrm{~cm}$ long) of many more flowers and somewhat obliquely rhombic (not obliquely obovate-oblanceolate), narrower (1.5 versus $2.8 \mathrm{~mm}$ ) petals.

Subtribe Spiranthinae Lindl. (Garay, 1982; Salazar, 2003: 164; Salazar et al., 2003).

Sarcoglottis Presl, Rel. Haenk. 1: 95, t. 15. 1827 (Garay, 1982; Salazar, 2003: 246).

Sarcoglottis maroaënsis G. A. Romero \& Carnevali, sp. nov.

TYPE: Venezuela. Amazonas: Municipio Autónomo Maroa, carretera Yavita-Maroa, cerca del aeropuerto, $100 \mathrm{~m}$, "hierba terrestre, raíces carnosas, hojas en el lado superior rojizas con manchas verde obscuro, en el lado inferior rojo-moradas con la nervadura principal

Right: Figure 1. A-B Ligeophila gavilanensis Ormerod \& G. A. Romero. A. Inflorescence. B. Closeup of flowers. C-D. Sarcoglottis maroaënsis G. A. Romero \& Carnevali. C. Inflorescence. D. Closeup of flowers. Photographs in situ by G.

A. Romero-González. A-B based on Romero et al. 3066; C-D based on Romero et al. 3620. 


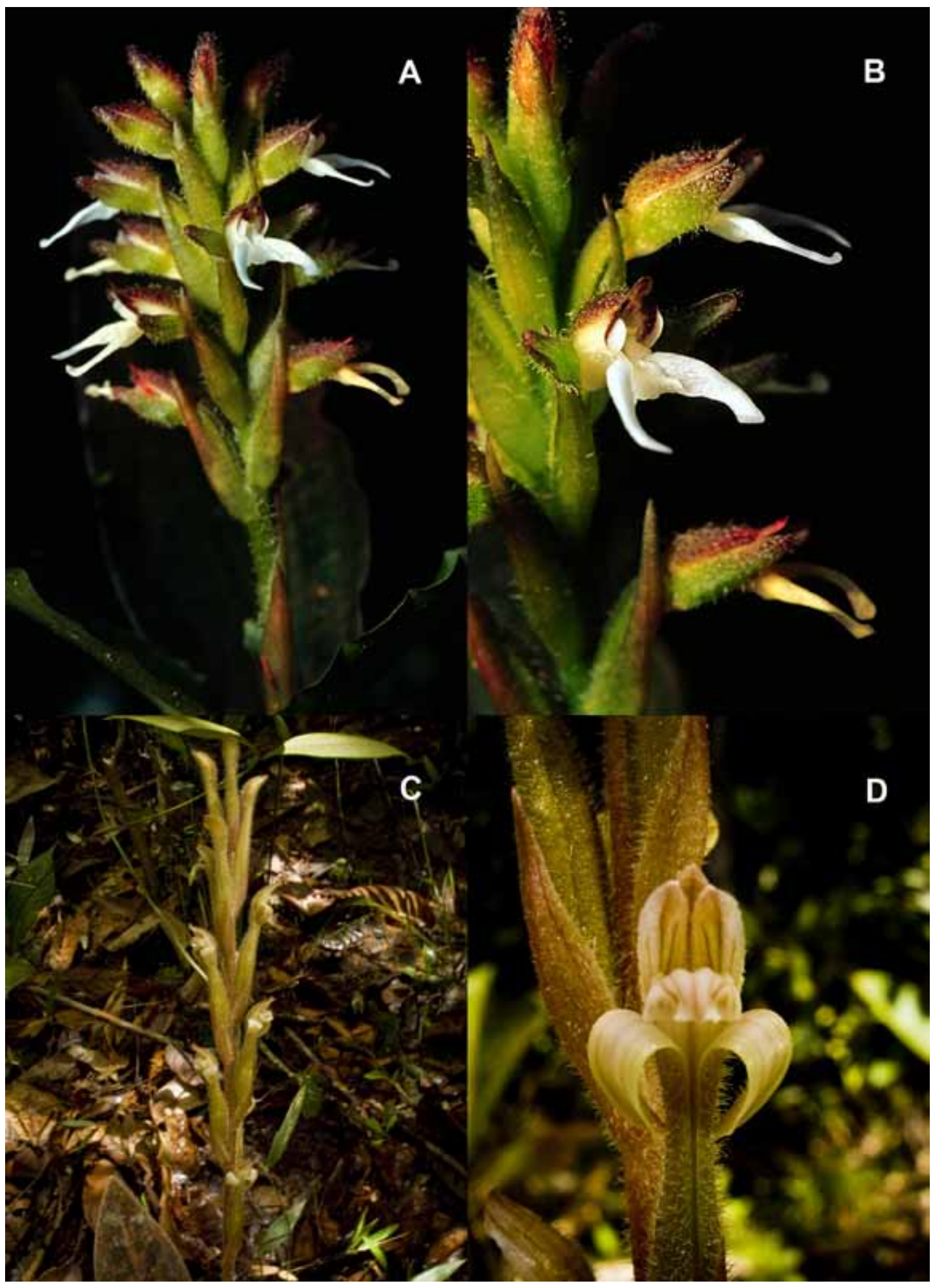



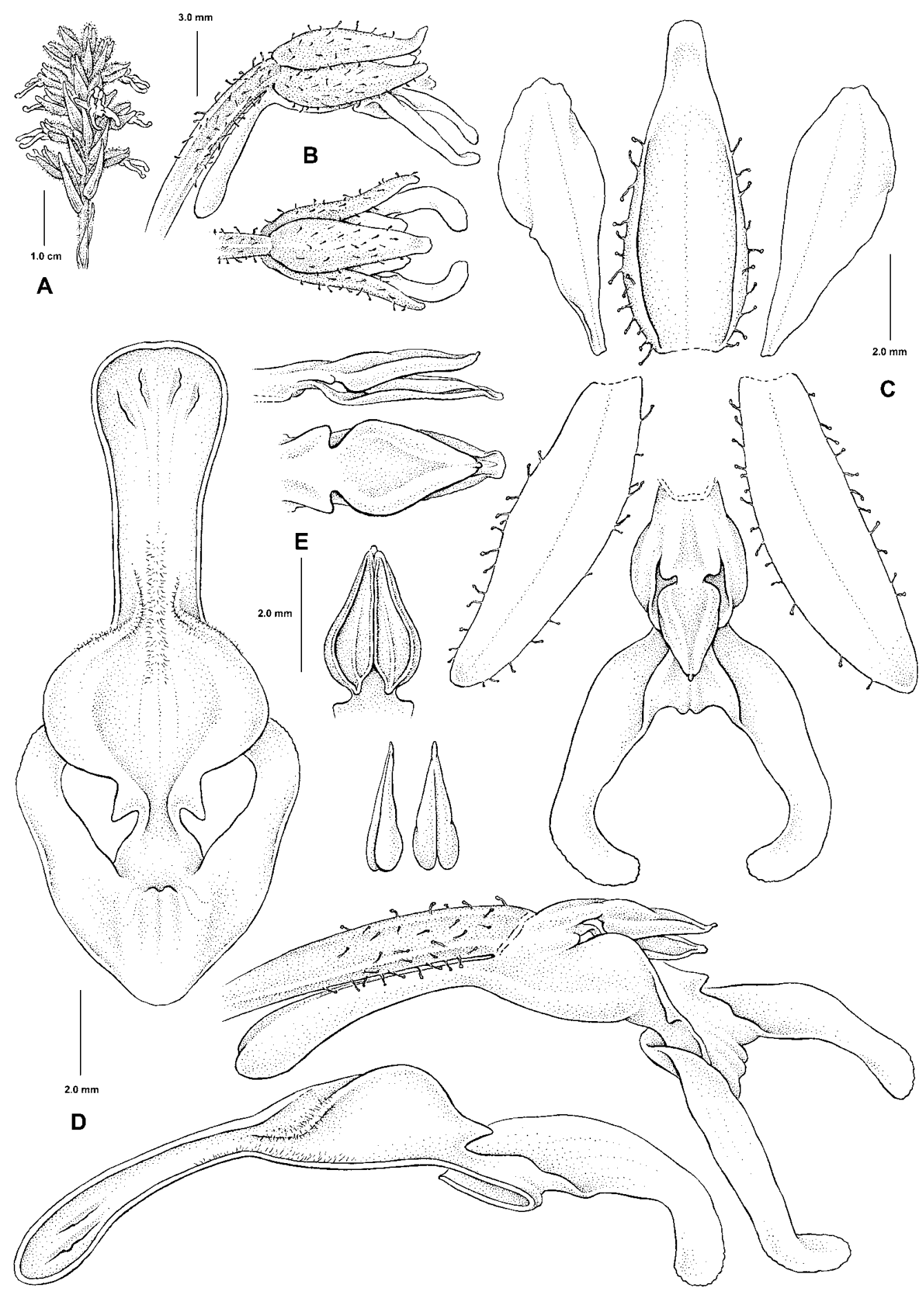

Figure 2. Ligeophila gavilanensis Ormerod \& G. A. Romero. A. Inflorescence. B. Two views of the flower. C. Floral diagram. D. Three views of the labellum. E. Three views of the column and two views of the pollinarium. Drawn by Bobbi Angell based on the holotype. 
roja, pedúnculo rosado, obscuro en la base, más pálido hacia el ápice, brácteas rojizas, sepalos verde pálido con nervios rojo pálido, pétalos y labelo crema con nervios rojo pálido", 29 July 2006, G. A. Romero, C. Gómez \& G. Gerlach 3620 (Holotype: TFAV; Isotype: AMES). FIG. 1B-C, 3.

A Sarcoglottis metallica (Rolfe) Schltr. floribus rubentibus ac foliis item rubentibus et maioribus, a Sarcoglottis ventricosa (Vell.) Hoehne inflorescentia laxiore non lanuginosa, floribus minoribus necnon forma segmentorum floralium diversa.

Terrestrial herbs. Roots clustered, fleshy. Leaves $3-6$, in a basal rosette, petiolate, dark brown above with dark green and lighter red spots, light reddish brown throughout below, with a prominent, reddish central nerve and two additional flat, reddish nerves on each side; petiole reddish, lighter toward the base, $3.0-5.0 \mathrm{~cm}$, narrow, decurrent; blade up to $18.0 \mathrm{x}$ $4.50 \mathrm{~cm}$, elliptic lanceolate to oblanceolate, acute, attenuate. Inflorescence a 10-flowered raceme, multilateral. Peduncle $7.0 \mathrm{~mm}$ in diameter at the base and $5.0 \mathrm{~mm}$ in diameter below the rachis, erect, glandular; bracts reddish, 4, shorter than the internodes, acute, herbaceous, glandular. Rachis $14.0-15.0 \mathrm{~cm}$, reddish, densely glandular. Floral bracts reddish, lighter toward the base, 15-18 $\mathrm{mm}$ long, lanceolate, acute, herbaceous, glandular throughout. Flowers erect. Pedicel $5.0 \mathrm{~mm}$ long, twisted. Ovary yellowish green, $25.0-39.0 \mathrm{~mm}$ long, glandular-pubescent throughout. Dorsal sepal $11.0-12.0 \times 3.0-3.2 \mathrm{~mm}$, oblong-lanceolate, acute, sparsely glandular-pubescent outside, 3-nerved. Lateral sepals yellowish green dorsally, light cream ventrally, fused with the ovary for $5.0-6.0 \mathrm{~mm}$, free parts reflexed, 9.0-10.0 × 3.5.0-4.0 mm, oblanceolate-falcate, acute, sparsely glandularpubescent outside, 5-nerved, the nerves dark brownish-red. Petals light cream, 10.0-11.0 × 2.5 $\mathrm{mm}$, oblanceolate, acute, asymmetric, glandular along the outer margins, 3-nerved, the nerves dark brownish red. Labellum subsessile, thin, constricted near the apex (the constriction marking the separation between hypochile and epichile), light cream with dark brownish markings; hypochile 16.0-18.0 x 4.5$5.0 \mathrm{~mm}$, cuneate in the densely glandular basal half, obovate above, with two fleshy, digitate retrorse auricles at the base; epichile $3.0 \times 5.0 \mathrm{~mm}$, more or less transversely elliptic, crenate and plicate along the margins. A roughly V-shaped, rugose thickening starts near the apex of the epichile and extends into the distal part of the hypochile. Column cream, 6.0-7.0 mm long, erect; column foot adnate to the ovary. Anther $4.5-5.0 \mathrm{~mm}$ long and $3.0 \mathrm{~mm}$ wide. Rostellum remnant thickened at the margins, truncate. Pollinarium yellow, $4.5 \mathrm{~mm}$ long, viscidium whitish, $1.5 \mathrm{~mm}$ wide (description based on a fresh specimen and on flowers preserved in alcohol).

Eтymology: Named after the type locality, Maroa, the capital of the municipality.

AdDitional SPECIMEN EXAMINED: VENEZUELA. Amazonas: municipio Autónomo Maroa, alrededores de Boca Chico, 100 m, 23 January 1998, "hierba terrestre, entre la hojarasca, hojas rojizas con manchas rojas más claras, sin flores, único individuo visto", $G$. A. Romero, C. Gómez \& L. M. Campbell 3177 (TFAV); municipio Autónomo Atabapo, Cerro Yapacana, 1200 $\mathrm{m}$, "flowers brown-green, leaves spotted with purple brown", 3 January 1953, B. Maguire, R. S. Cowan \& J. J. Wurdack 30686 (NY).

Distribution: Venezuela, Amazonas (endemic).

This plant previously had been detected along the Yavita-Maroa road several times but never with flowers. As such, it had been preliminarily identified as Pelexia callifera (C.Schweinf.) Garay, a species with which it shares many vegetative characters. However, an examination of the flowers of the type showed that the plant clearly was not referable to Pelexia Poit. ex Lindl. but to Sarcoglottis Presl (see keys and generic descriptions in Garay, 1980 and Salazar, 2003: 166-168, 232, 234, 247). Further comparison to the known species of Sarcoglottis showed that is was an undescribed species. In shape and size of labellum it is similar to S. metallica but the new species differs in the cream flowers with dark reddish veins in the sepals, petals, and labellum, and the leaves of different color. In flower color it is similar to $S$. ventricosa (Vell.) Hoehne (synonym: $S$. rufescens Klotzsch) but the inflorescence of $S$. maroaënsis is more lax and not lanate, the flowers are smaller, and lateral sepals and labellum are different. 


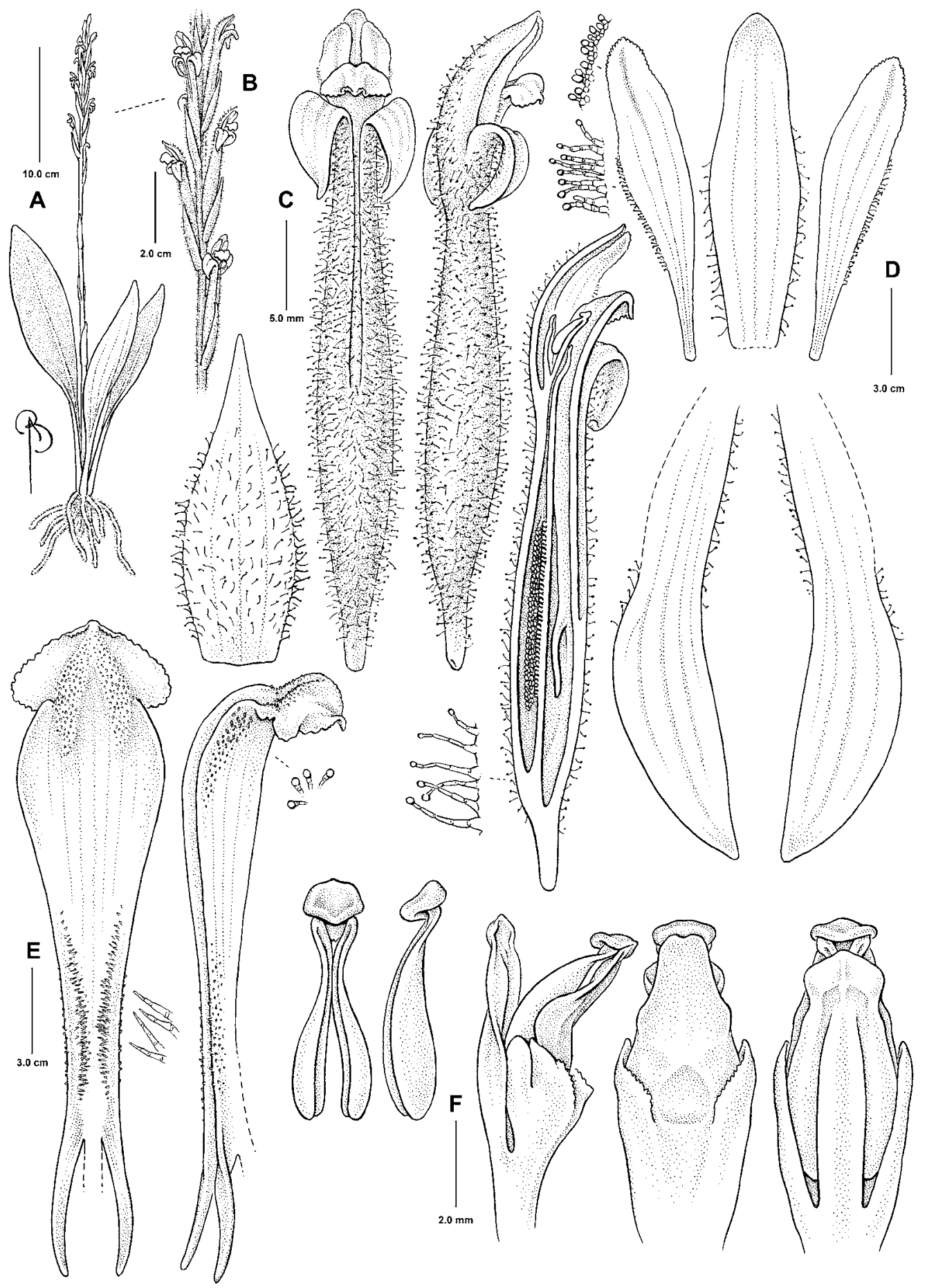

Figure 3. Sarcoglottis maroaënsis G. A. Romero \& Carnevali. A. Plant. B. Inflorescence. C. Three views of the flower. D. Floral diagram. E. Two views of the labellum. F. Three views of the column and two views of the pollinarium. Drawn by Bobbi Angell based on the holotype. 
Sarcoglottis stergiosii Carnevali \& I. Ramírez, 3: 124, fig. 12. 1993 3: 124, fig. 12. 1993.

TYPE: Venezuela. Amazonas: municipio Autónomo Río Negro, selva pluvial, alrededores de San Carlos de Río Negro y camino que conduce a Solano, 23-29 July 1982, "hierba, flores blancas", B. Stergios \& G. Aymard 4400 (holoype: VEN; isotypes: NY, PORT, TFAV).

Additional SPECIMEN EXAMined: COLOMBIA. Amazonas: Río Apaporis, Cachivera de Jirijirimo y alrededores, $250 \mathrm{~m}$, "Terrestrial, flowers white, leaves mottled grey-purple", 16 September 1951, R. E. Schultes \& I. Cabrera 14031 (AMES).
Here we report the isotype at NY that was not cited in the protologue, and extend the distribution of this species, previously thought to be endemic to Venezuela (Carnevali \& Ramírez 2003), to the Colombian Amazon.

AcKNOWEDGMENTS. We are grateful to K. Gandhi (HUH) for his advice on botanical nomenclature, and to the following herbaria for handling loans and providing support during our visits: K, MO, NY, PORT, TFAV, US, and VEN. We also thank Bobbi Angell for the drawings, Bruno Manara for the Latin diagnoses, and the Arizona Orchid Society of Arizona (O.S.A.) and the Massachusetts Orchid Society (M.O.S.) for their generous financial support (to G.A.R.-G.).

\section{Literature Cited}

Carnevali, G. \& I. Ramírez. 2003. Sarcoglottis Presl. Pages 552-553 in: J.A. Steyermark, J.A., Berry, P.E., Yatskievich K. \& Holst, B.K. [gen. eds.]. Flora of the Venezuelan Guyana 7: 200 - 619. Missouri Botanical Garden, St. Louis.

Garay, L. A. 1977. Systematics of the Physurinae (Orchidaceae) in the New World. Bradea 2: 191—208.

Garay, L. A. 1982. A generic revision of the Spiranthinae. Bot. Mus. Leafl. 28: 277—425.

Ormerod, P. 2009. Studies of neotropical Goodyerinae (Orchidaceae) 4. Harvard Pap. Bot. 14, 2: 111-129.

Ormerod, P. \& P. J. Cribb. 2003. Subtribe Physurinae. Pages 63-153. in: A. L. Pridgeon, P. J. Cribb, M. W. Chase \& F. Rasmussen (eds.), Genera Orchidacearum 3. Oxford University Press, Oxford.

Salazar, G. A. 2003. Subtribe Spiranthinae. Pages 164-278 in: A. L. Pridgeon, P. J. Cribb, M. W. Chase \& F. Rasmussen (eds.), Genera Orchidacearum 3. Oxford University Press, Oxford.

Salazar, G. A., M. W. Chase, M. A. Soto Arenas \& M. Ingrouille. 2003. Phylogenetics of Cranichideae with emphasis on Spiranthinae (Orchidaceae, Orchidoideae): evidence from plastid and nuclear DNA sequences. Amer. J. Bot. 90: 777-795. 
LANKESTERIANA 